\title{
The diagnostic and therapeutic challenges of infective endocarditis presenting as acute stroke
}

\author{
Robert Jennings, ${ }^{1}$ Daniel Hammersley, ${ }_{1}^{1}$ Jane Hancock, ${ }^{2}$ Christopher Blauth ${ }^{2}$
}

${ }^{1}$ Frimley Health NHS Foundation Trust, Frimley, UK

${ }^{2}$ St Thomas Hospital, London, UK

Correspondence to Dr Daniel Hammersley, djhammersley@gmail.com

Accepted 14 April 2017

\section{DESCRIPTION}

An 81-year-old man presented with suddenonset slurred speech and right-sided weakness commencing 2 hours previously. Initial National Institute of Health Stroke Scale score was 13. Non-contrast CT brain scan excluded haemorrhage, and he received intravenous thrombolysis. Medical history included tissue aortic valve replacement. On arrival, his temperature was $38^{\circ} \mathrm{C}$. Two hours after thrombolysis he had two seizures, and his Glasgow Coma Scale score dropped from $15 / 15$ to $6 / 15$ (breakdown: eyes 1, voice 1, motor 4). Repeat CT demonstrated a left middle cerebral artery territory infarct, and he was transferred to the intensive care

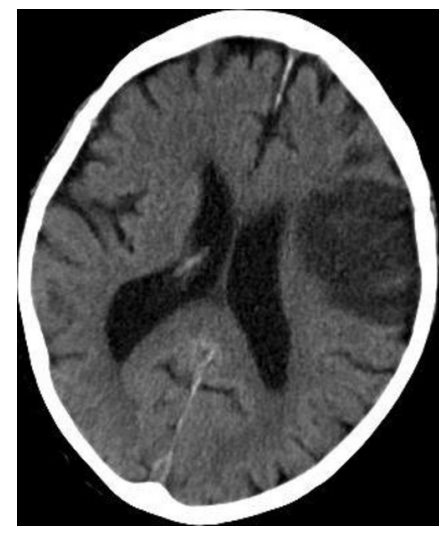

Figure 1 Non-contrast CT head showing a left middle cerebral artery territory infarct.

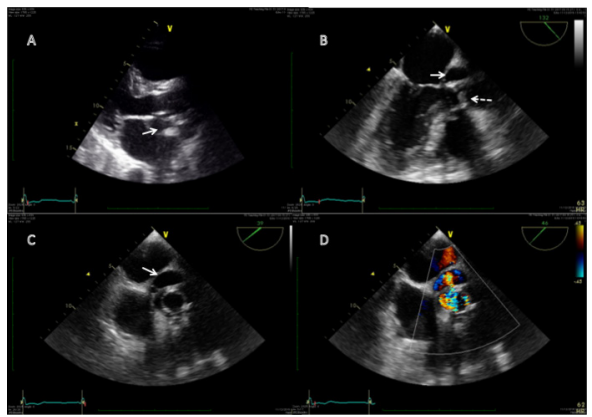

Figure 2 (A) Transthoracic echo (TTE) parasternal long axis window showing aortic root abscess (solid white arrow); (B) Transoesophageal echo (TOE) midoesophageal long axis view showing a $10 \times 6 \mathrm{~mm}$ vegetation on tissue aortic valve (dotted white arrow) and aortic root abscess (solid white arrow); (C) TOE midoesophageal aortic valve short axis view showing aortic root abscess (solid white arrow); (D) TOE midoesophageal aortic valve short axis view showing colour Doppler flow into the abscess via fistulation. unit (figure 1). Transthoracic and transoesophageal echo identified an aortic root abscess and $10 \times 6 \mathrm{~mm}$ aortic valve vegetation (figure 2 ). He was transferred to a cardiothoracic centre and underwent successful aortic root replacement. Blood cultures were negative, but aortic valve biopsy grew staphylococcus epidermidis. He remains aphasic with a right haemiplegia.

Stroke occurs in approximately 35\% of infective endocarditis cases with an inpatient mortality estimated at $20 \% .^{1}$ There is a paucity of data, but treatment with thrombolysis is probably less likely to result in a positive outcome than in non-infective stroke with a greater risk of intracerebral haemorrhage. ${ }^{12}$ Infective endocarditis is a contraindication to thrombolysis in many guidelines and should be considered from the outset, particularly given the time pressures in acute stroke care. ${ }^{1}$ Thrombectomy may be the treatment of choice, but there is currently minimal trial data to support this. ${ }^{12}$ In the case described, a CT angiogram was not performed, and thrombectomy was not considered. Early cardiac surgery within 72 hours is associated with reduced risk of secondary haemorrhage from intraoperative heparin use.

Learning points

- Infective endocarditis as a cause of acute stroke should be considered in the presence of fever, raised inflammatory markers, heart murmurs, previous valve replacement, stigmata of infective endocarditis or young people with minimal cardioembolic risk factors.

- Thrombolysis is less likely to be successful and may be associated with greater risk of bleeding than in non-infective causes of stroke.

- Thrombectomy may be beneficial, but there is a lack of trial data to guide best practice.

Contributors RJ contributed to the initial write up, preparation of images and submission. DH contributed to revisions of the draft and preparation of images. JH and CB were supervisors.

Competing interests None declared.

Patient consent Obtained.

Provenance and peer review Not commissioned; externally peer reviewed.

(C) BMJ Publishing Group Ltd (unless otherwise stated in the text of the article) 2017. All rights reserved. No commercial use is permitted unless otherwise expressly granted.

\section{REFERENCES}

1 Jiad E, Gill SK, Krutikov M, et al. When the heart rules the head: ischaemic stroke and intracerebral haemorrhage complicating infective endocarditis. Pract Neurol 2017;17:28-34. 


\section{Images in...}

2 Brownlee WJ, Anderson NE, Barber PA. Intravenous thrombolysis is unsafe in stroke due to infective endocarditis. Intern Med J 2014;44:195-7.

3 Piper C, Wiemer M, Schulte HD, et al. Stroke is not a contraindication for urgent valve replacement in acute infective endocarditis. J Heart Valve Dis 2001;10:703-11.

Copyright 2017 BMJ Publishing Group. All rights reserved. For permission to reuse any of this content visit

http://group.bmj.com/group/rights-licensing/permissions.

BMJ Case Report Fellows may re-use this article for personal use and teaching without any further permission.

Become a Fellow of BMJ Case Reports today and you can:

- Submit as many cases as you like

- Enjoy fast sympathetic peer review and rapid publication of accepted articles

- Access all the published articles

- Re-use any of the published material for personal use and teaching without further permission

For information on Institutional Fellowships contact consortiasales@bmjgroup.com

Visit casereports.bmj.com for more articles like this and to become a Fellow 